に $0.1 \mu \mathrm{g}$ の水銀を加え，乙の溶液の水銀吸光度を 3 榆体 について測定した，検体すべてに0.1/g の吸光度を示

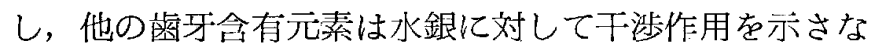
かった．またこの結果より崡牙含有無機水銀量は $0.1 \mu \mathrm{g}$ 以下であろうと推察した。。っって感度を上げ $0.01 \mu \mathrm{g} / d \ell$ を最終単位として曾牙含有無機水銀量を測定した，乳菌 15検体，永久菌 16 検体では，乳歯 $0.142 \pm 0.127 \mu \mathrm{g} / \mathrm{g}$, 永久電 $0.051 \pm 0.043 \mu \mathrm{g} / g$ 亗った。 また男女差では, 女性が男性に比し多く含まれていた，今後, 症例数を増 していく所存である.

\section{3. 嚥下闘について}

。中村修一・友松俊之・濤崎亘三郎（生 理）

1）研究目的：提食する時, 嚾下は無意識に行なって いる，矌下するまでの勗嚼回数には個人差はあるが，個 人については翼慣によりおおよそ決まっている。この燕 下時における食品の粉哗状態を調べる目的で実験を行な った．2）研究方法：10名の被験者にあらかじめ生米 $1 g$ を自然に咀嚼，臙下させた。このテストを10回行い

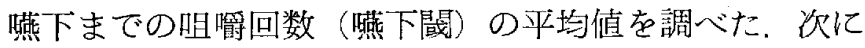
この咀嚼回数だけあらたに生米を咀嚼させ，ての試料を 節い分けた。試料の粉砕状態は， 8，14，28，48，100 Mesh の穊上量を乾燥重量\%で示した。次に被験者に対 し，人工試料を用いて咀嚼エネルギーを測定した。咀鲅 エネルギーは横田らの方法で行なった。また生米と同様 にピーナッ $3 g$ を用い，柤嚼テストを10回繰返し，嚥下

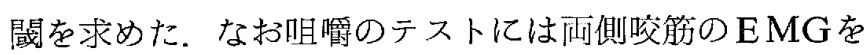
記録し咀嚼回数，咀嚼側などを調べた。 3 ) 奏駼結果 ：䁩下闇まで生米を咀嚼させ，その試料について節上量 を調べてみたとてろ $8 \mathrm{M}$ 管䎲試料が残ったもの4名， 通過したもの6名であった。14Mより小さい穊では全被

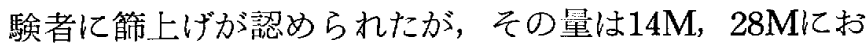
いて個人差が著しかった，逆に穊上量は $48 \mathrm{M} ， 100 \mathrm{M} の$ 場合個人差が少なかった。各穊における穊上量の比較は 10 名の平均で $14 \mathrm{M}, 8.3 \pm 7.5,28 \mathrm{M}, 17.9 \pm 7.3,48 \mathrm{M}$, $17.5 \pm 2.5,100 \mathrm{M}, 10.8 \pm 2.5$ 重量\%であった。生米 1 $g$ とピーナツ $3 g$ の嚥下䦭と咀嚼能力との間の相関係数 はそれぞれ $\mathrm{r}=0.03, \mathrm{r}=0.30$ であった。生米 $1 \mathrm{~g}$ とピ

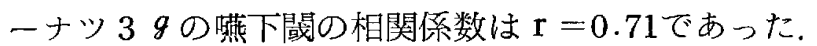

結論：1）生米を試料とした場合，舆下閾に扔いて大き い粒子が残っている者とそうでない者があった，前者の 100M通過量は少なく後者においては多かった，2）14 M，28Mの穊上量は 48M，100Mの節上量に比心，個人 差が大きかった，3）曖下閾と咀㘉能力との相関は生米
を試料にした場合もピーナツの場合も認められなかっ た．4）生米とピーナツの嚥下閾には両者の間に相関を 認めた。

\section{4. 巨大なる正中口蓋囊胞の 1 例}

$$
\begin{array}{r}
\text { 。豊島健治・陶山新二・山田長敬（1口外） } \\
\text { 迫田隅男（口 病） }
\end{array}
$$

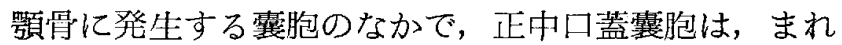
なるのとされ，本邦における報告例も比較的少ない。

今回，われわれは，45才の男性に生じた巨大な正中口 覑襄胞の 1 症例を経験したので，報告する。

症例：A．K，，45才，男性，主訴：口蓋正中部の膨 隆，家族歴および 既往歴：特記すべき事項なし，現病 歴：初診 4 力月前, 口蓋正中部の膨隆に気付いたが，疼 痛および大きさの変化もなく，放置していた。回脡外所 見：特記すべき事項なし，口腔内所芫：口蓋中央部に， 鳩畉大の表面平滑で，境界明瞭な膨隆があり，圧痛はな く，波動が触知される。穿刺により，粘稠な緑褐色の内

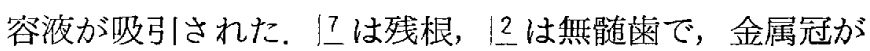
装着されている以外，全て有骫迶である。X線所見：口 蓋の大半を占める学房性囊胞像を認める，処置ならびに 経過：全身麻酔下で，副腔形成法を行なった。術後 8 週 間を経過しているが，経過良好である。なお，囊胞壁は 一部鼻腔底粘膜と癒着していた。病理組織学的所見：多 列織毛抢よび扁平上皮と，慢性焱症性変化を伴う結合組 織よりなる上皮性襄胞像を呈する。

以上, 臨床的所見, $X$ 線学的所見, 病理組織学的所見 より，正中口蓋豊胞と診断し，その概要を報告した。

䝷 問 高 木 (矯 正)

霊胞による口蓋の骨の吸収が広範囲であるが，乙の場 合，口蓋はまた骨の repair があるか.

応 答 豊 島（1口外）

日時の䌊過につれて，ある程度，骨の再成が期待でき る.

質 問 草 場 (外 科)

術後における口蓋の骨再生について，口蓋における骨 欠損がどの程度の大きさ位まで，骨再生を期待出来る か.
応 答
山田(1口外)

骨腔の大きさによる骨再生は，年令などにより差があ ると考える。教室で络大きな骨腔には自家骨移植，他家 骨移植など行なって，骨腔の回復をはかって来ている が，本症例は局所自家骨の採取が困難のため，骨移植を 行なわず副腔形成法を用いた。 